\title{
EUROPEAN RAILWAY INFRASTRUCTURE: A REVIEW
}

\author{
Lucia Knapcikova \\ Technical University of Košice, Faculty of Manufacturing Technologies with a seat in Prešov, Department of Industrial \\ Engineering and Informatics, Bayerova 1, 08001 Prešov, Slovak Republic, \\ lucia.knapcikova@tuke.sk (corresponding author) \\ Rob Konings \\ Delft University of Technology, Faculty of Architecture and The Built Environment, \\ Department OTB - Research for the Built Environment, Julianalaan 134, 2628 BL Delft, The Netherlands, \\ J.W.Konings@tudelft.nl
}

Keywords: railway, freight, logistics junction, European Union

Abstract: Presented paper deals with important freight railway infrastructure review in the Europe. The shrinking situation on the road makes companies do to think more and more about alternative ways of transporting goods from remote industrial zones quickly, safely and taking into account an ever more important environmental aspect. The quantity of goods transported in freight transport is increasing every year, which is also reflected in the unfavourable increase in road transport. Road journeys are often used, roads are more prone to wear, and their repair requires significant financial costs each year. Important part of presented paper is focused on the traffic situation that the future of transport will be on the rail. Moving transport from road to rail is also the intention of the European Union, which is declared in the "White Paper on Transport". In addition to other targets, it states that by year 2030 the $30 \%$ of road freight over the $300 \mathrm{~km}$ should be transferred to other modes of transport such as rail or waterborne transport, and by year 2050 this should represent more than $50 \%$ of freight transportation.

\section{Introduction}

The railway infrastructure in the Europe say about $216,000 \mathrm{~km}$ network of active railways in the European Union (EU). The total cost of international train transportation is different in whole Europe [1,2]. It depends on access charges, competition rates, travel time, and economies of scale. Specifically, the significant fixed additional costs associated with the first and last mile (e.g. loading/unloading in terminals) are more evenly distributed at medium and long distances. As a result, the total cost of a tonne-kilometer for rail freight at these distances may be lower than for the carriage of the same goods by road [2]. Promoting more efficient and sustainable modes of transport, and in particular rail freight transport, has been a key part of EU policy over the last 25 years. As early as year 1992, the European Commission (EC) set a shift in the balance between transport modes as one of its main objectives. The European Commission confirmed the importance of refreshing railways infrastructure and formed the objective of maintaining the market share of rail freight in the Member States of Central and Eastern Europe. On the other side, the Commission sets the target of moving up to $30 \%$ of the freight travelled by distances exceeding $300 \mathrm{~km}$ for other modes of transport, such as rail or water, by 2030 and more than 50\% by year 2050 [3].

During the year 2013, the EU revised the previous guidelines on the TEN-T (Trans European Network for Transport, see on the Figure 1) project in order to define a core network of transport infrastructure that incorporates all means of transport, but pays special attention to railways.

In the Regulation No. 913/2010 are defined (among other) three most important rail freight corridors (RFC) through Belgium:

1. RFC Rhine-Alpine

-With direction via Zeebrugge-Antwerp /Amsterdam/ Rotterdam -Duisburg-Basel-Milan-Genoa

2. RFC North Sea-Mediterranean

-With direction via London/Dunkirk/Lille/Liège/Pari s/Amsterdam-Rotterdam-Zeebrugge/AntwerpLuxembourg-Metz-Dijon-Lyon/Basel-Marseille

3. RFC North Sea-Baltic

-With direction via Wilhelmshaven/Bremerhaven/Ha mburgúAmsterdam/Rotterdam/Antwerp/ Aachen/Berlin Warsaw-Terespol/Kaunas/Falkenberg-Prague/WrocławKatowice [2]. 


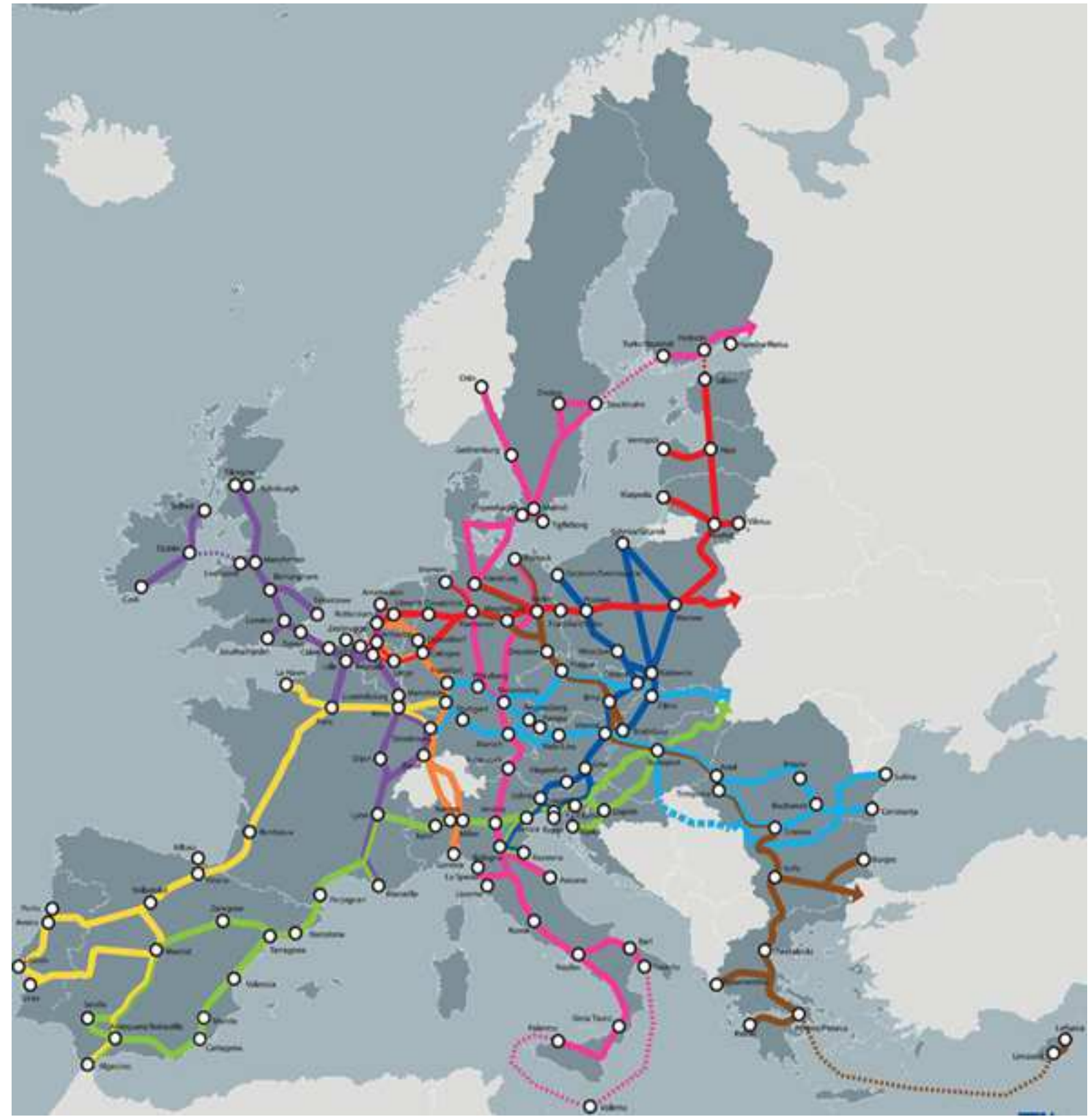

Figure 1 Trans-European transport network [2]

\section{Legend to the Figure 1:}

Dark blue line- Corridor "Baltic-Adriatic",

Red line- Corridor "North Sea- Baltic",

Green line- Corridor "Mediterranean",

Brown line- Corridor "Orient-East- Med",

Pink line- Corridor "Scandinavian- Mediterranean",

Orange line- Corridor "Rhine-Alpine",

Yellow line- Corridor"Atlantic",

Violet line- Corridor "North Sea- Mediterranean",

Sky blue line- Corridor "Rhine-Danube".

The formation of new industrial areas in China and Russia offers new and interesting challenges for logistics companies. An effective solution to cover the long distances that goods have to overcome to the destination station, the transport of sensitive, special or oversized goods, is an ideal transportation by rail. By the year 2015, the number of China-European international trains has risen by more than $100 \%$ annually. In the past year alone, 2000 trains across the Polish-Belarusian border and transhipment terminals were transported in China-Europe route in two directions. Undoubtedly, the situation in Ukraine has also been extremely hard on the current state. Generally, the transit time from China to Europe according to the selected mode of transport:

- Air transport 3-7 days,

- Maritime transport 28-38 days, 
- Rail transport 14-22 days.

A part from railway undertakings that hold a licence and a safety certificate, other applicants (shippers, freight forwarders, etc.) can also apply for capacity on the corridors (Fig. 2) [4].

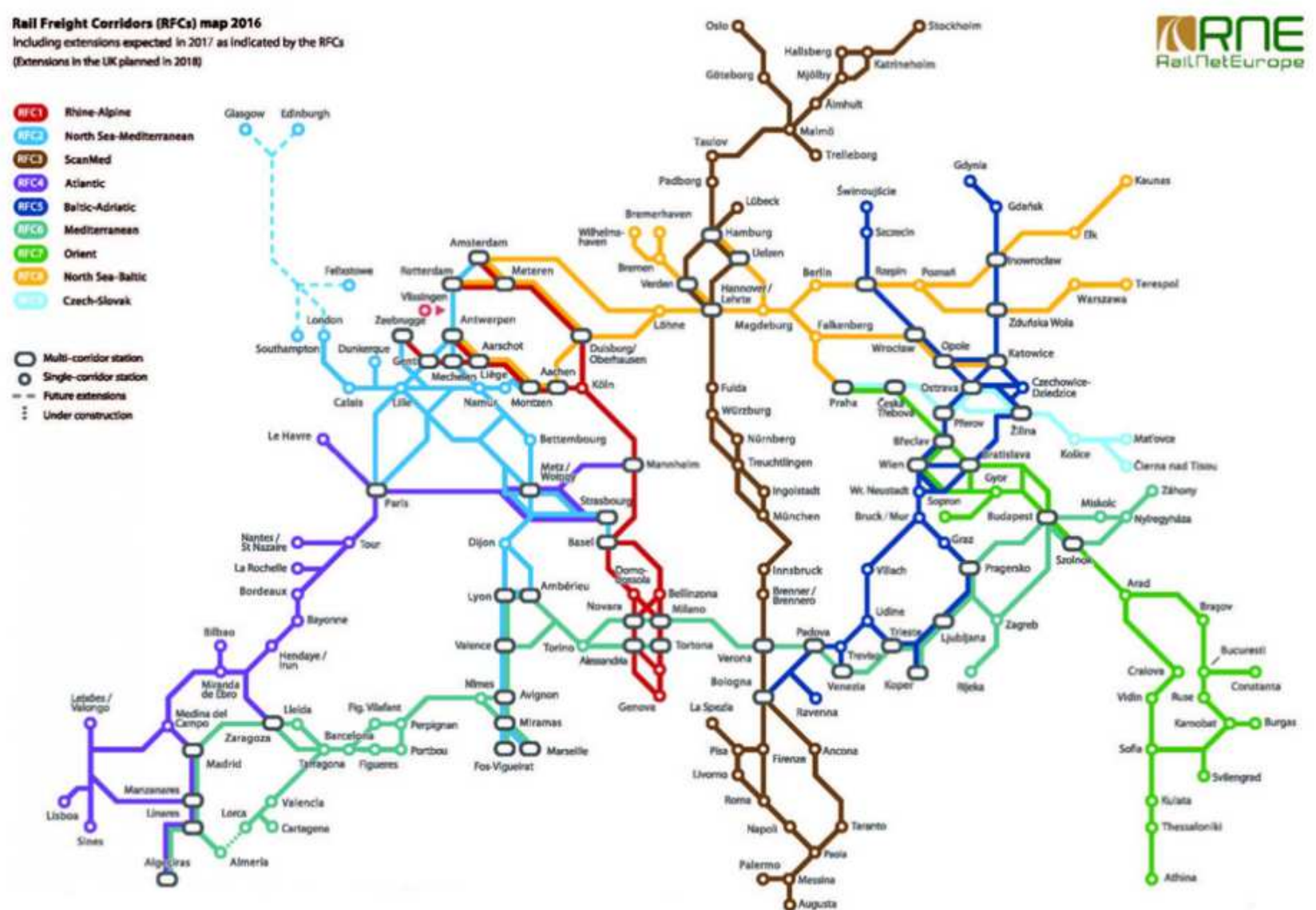

Figure 2 Rail freight corridors map (y. 2016) [3]

Legend to the Figure 2:

RFC- Rail Freight Corridor,

RFC1- Corridor "Rhine-Alpine",

RFC2- Corridor "North Sea- Mediterranean",

RFC3- Corridor "Scandinavian- Mediterranean",

RFC4- Corridor "Atlantic",

RFC5-Corridor "Baltic-Adriatic",

RFC6-Corridor "Mediterranean",

RFC7-Corridor "Orient",

RFC8-Corridor "North Sea- Baltic",

RFC9- Corridor "Czech-Slovak".

To strengthen the competitiveness of rail freight transport should the rail network to meet the needs of the freight sector. It is generally accepted, in particular:

- to allow easy crossing of borders because of rail freight is more competitive at medium and long distances (what in Europe generally means the transport of goods between different EU Member States)
- to provide good connections to-from different freight producers and support the development of multi-modal logistical platforms,

- to provide infrastructure and facilities for cargo transportation,

- to support rail-road transport if needed or combined transport),

- to allow longer trains to reduce unit costs per tonne of transported goods [2].

\section{Freight railway infrastructure in European Union}

On a global scale, the distribution of railways is uneven, for several reasons. The first is that, from a technical point of view, the railways must be fairly flat terrain and mostly at the level of the surrounding terrain. Secondly, railways are being built in places with higher density of occupation and increased levels of economic activity so they are economically feasible. The competition of other types of 
transport also affects distribution of railway networks. In places where there is a well-developed road or air transport, it is difficult to keep rail transport in a dominant position.

The poor performance of rail transport in terms of volume and share of modes of transport in the EU does not help the average service speed of freight trains [2,5]. In a nutshell, expensive trains travel slowly, and their speed has not increased significantly in the last decade. Every day, thousands of goods are shipped across the EU to factories, warehouses and customers. Rail transport is in direct competition with road haulage, like freight transports. In other words, transporters choose transport modes based on commercial criteria rather than on the political priorities of the EU [6].

According to International Railways Association, the total length of railways was at the end of 2015, 1039230 kilometres. The area of North and South America was the largest with the $37 \%$, the second largest of the total length of railways in the world was Europe with the $26 \%$.

In the European Union, the regulation requests the member state to establish international market-oriented Rail Freight Corridors (RFC) to meet next challenges [7]:

- cooperation between infrastructure managers and infrastructure development,

- building the right balance between freight and passenger railway traffic along the Rail Freight Corridors (RFC),

- $\quad$ giving adequate capacity and priority for freight in hand in hand with market needs,

- intermodality between rail and other transport modes,

- integrating terminals into the corridor management and development [7].

\subsection{Infrastructure efficiency of freight railway funding by European Commission}

Transport requirements constantly require optimization of transport links, efficient use of means of transport, transport routes and smoothness and transport safety. The issue of traffic accidents, whether on road or road rail transport is a socio-economic problem in all spheres of human activity. Today's, the high-quality services of railway undertakings and carriers in general and for the competitiveness of rail freight, say that the infrastructure manager must not only renovate and modernize the railway network to meet the specific needs of rail freight but also regularly maintain it [5]. Despite the business plans and indicative rail infrastructure development strategies identified by infrastructure managers, railways more frequently used by freight trains and limited passenger transport are generally closed and speeds are limited. This has an impact on the performance of the rest of the rail network in terms of the volume of goods transported, including those that could potentially benefit from EU funds, since their ability to transport goods from the place of production to the consumer centres is limited. The inadequate priority given by infrastructure managers for the maintenance of railways that use more frequent freight trains is the result of prioritizing passenger transport routes that are politically more sensitive and, in some cases, the low profits generated by rail freight $[6,7]$.

The provision of railway services is multidimensional. In economic terms the railway company is a multi-product firm. It is a very capital intensive business, economies of scale and density can be relevant and some natural monopoly characteristics are present. In most contexts and on most continents, a competitive railway market is not a straightforward concept [8].

\subsection{Financial support of freight railway infrastructure by European Commission}

The government, the users of the railway network or the users of railway services and the economic regulator, these are three most important parts of railway funding [8]. Funding support provided by the EU's financial assistance is mainly focused on the construction of new railway lines or the renewal and upgrading of existing lines, which usually involves speeding up and redress or adapting to interoperability requirements. Except for line projects used exclusively by passenger trains (in general, high-speed lines) or in rare cases, trains used only by freight trains for investment in railway infrastructure benefit both modes $[6,8]$. To a lesser extent, investment in rail rolling stock is also supported by the EU budget, several noninfrastructure measures to support the implementation of EU rail policy and research projects focus mainly on the construction of new railway lines or the renewal and upgrading of existing lines, which usually includes increase speed and axle wagon load or adaptation to interoperability railways requirements.

\section{Statistical results of freight rail transport across the European states}

They serve the industry and consumers every day, and there is an endeavour to provide them with technical and technological innovations, but focusing on this is not enough.

The following Table 1 describes a statistical data processing of the volume of freight rail transport that has been monitored and processed from 2006 to 2015.

Developing implementation studies and strategic approaches in the long run also need to be addressed. As one of the few countries, Finland has set up a comprehensive strategic plan for the transport of hazardous costs for the period up to 2015, which deals not only with the state but also with the challenges and new trends that are useful as a source of inspiration for other countries, including Slovakia. In this country, there is a particular unit.

The institutions are responsible for this hazardous goods transport strategy and also responsible for preparing the necessary legal framework [9]. It focuses on improving 


\section{EUROPEAN RAILWAY INFRASTRUCTURE: A REVIEW}

Lucia Knapcikova; Rob Konings

and developing supervision and management, education and services.

Table 1 Volume of freight rail transport in the Europe (statistical datas between y.2016-2015*)[10]

\begin{tabular}{|c|c|c|c|c|c|c|c|c|c|c|}
\hline GEOHTIME & 2006 & 2007 & 2008 & 2009 & 2010 & 2011 & 2012 & 2013 & 2014 & 2015 \\
\hline European Union (28 countries) & 100.4 & 100.9 & 98.8 & 91.5 & 94 & 92.6 & 90.7 & 91.6 & 90.4 & 90.1 \\
\hline Belgium & 98.9 & 94.1 & 86.7 & 78.6 & 79.5 & 75.6 & 75.3 & 76.3 & 73.8 & 72.5 \\
\hline Bulgaria & 92 & 89.7 & 92.8 & 110.6 & 118.4 & 117.3 & 132.7 & 144.1 & 144.8 & 159.6 \\
\hline Czech Republic & 106.1 & 97.9 & 98.1 & 89.8 & 99.7 & 103 & 98.4 & 103.9 & 100.9 & 101.8 \\
\hline Denmark & 88.1 & 85.8 & 81 & 74.1 & 67.6 & 72.4 & 73.1 & 70.7 & 70 & 65.7 \\
\hline Germany (Until 1990 former territory of the FRG] & 102.9 & 104 & 102.5 & 95.7 & 96.7 & 95.1 & 91.4 & 91.5 & 90.7 & 90.1 \\
\hline Estonia & 87.9 & 75.9 & 71.9 & 71.5 & 75.9 & 70.2 & 60.3 & 58.3 & 50.7 & 49 \\
\hline Ireland & 91.6 & 95.7 & 91.5 & 64.4 & 59.2 & 54.8 & 54.6 & 50 & 48.8 & 39.2 \\
\hline Greece & 134.6 & 107.6 & 111.8 & 114.9 & 126.9 & 96.2 & 104.6 & 98.3 & 99.6 & 102.5 \\
\hline Spain & 99.3 & 102.1 & 94.9 & 85.1 & 84.9 & 84.7 & 84.1 & 82.8 & 83.4 & 86.5 \\
\hline France & 100.3 & 101.5 & 95.5 & 82.6 & 83.7 & 84.7 & 79 & 78.2 & 75.4 & 70.7 \\
\hline Croatia & 105.6 & 104.8 & 110 & 100 & 98.1 & 96.2 & 95.8 & 98.8 & 101.2 & 110 \\
\hline Italy & 88.3 & 84.3 & 85 & 81.7 & 84.2 & 70.1 & 63.9 & 66 & 62.1 & 61.5 \\
\hline Cyprus & 80 & 78.8 & 82.5 & 61.9 & 68.9 & 59.5 & 58.5 & 44 & 37.9 & 39 \\
\hline Latvia & 87.5 & 90.9 & 95.6 & 93.8 & 100.8 & 114.5 & 111.7 & 103.5 & 103.7 & 102.4 \\
\hline Lithuania & 101.9 & 102.4 & 101.3 & 100.2 & 109.2 & 114.8 & 113.6 & 115.8 & 119.4 & 112.2 \\
\hline Luxembourg & 96 & 96.4 & 89.6 & 86.5 & 87.1 & 85.4 & 77 & 79.9 & 83.6 & 74 \\
\hline Hungary & 112.7 & 126.7 & 125.2 & 125.5 & 124.8 & 124.2 & 124.8 & 129 & 129.3 & 127.1 \\
\hline Malta & 98.2 & 94.4 & 91.4 & 93.7 & 90.5 & 89.3 & 87 & 83.2 & 76.9 & 71.5 \\
\hline Netherlands & 96.3 & 92.7 & 91 & 83.6 & 91.8 & 89.6 & 87.3 & 89.6 & 89.1 & 84.8 \\
\hline Austria & 103.9 & 99.2 & 93.3 & 80.8 & 82.6 & 80.6 & 74.9 & 71.8 & 73.1 & 71.7 \\
\hline Poland & 105.9 & 111.5 & 113.1 & 113.6 & 122.7 & 121.7 & 124.3 & 134.9 & 131.7 & 131.2 \\
\hline Portugal & 103.4 & 104.1 & 88.7 & 83.4 & 81.2 & 85.1 & 80.8 & 89.8 & 85.5 & 77.9 \\
\hline Romania & 98.2 & 94.4 & 83.8 & 64.1 & 59.5 & 58.8 & 61.9 & 63.6 & 61.7 & 66.1 \\
\hline Slovenia & 102.7 & 107.5 & 118.7 & 114.4 & 124.4 & 129 & 127.1 & 130.8 & 131.2 & 138.9 \\
\hline Slovakia & 92.7 & 98 & 97.3 & 92.3 & 91 & 91.4 & 90.4 & 92.3 & 93.2 & 93.4 \\
\hline Finland & 94.3 & 88.6 & 91.3 & 87.3 & 90.8 & 81.7 & 79.5 & 78.2 & 76.6 & 76.3 \\
\hline Sweden & 98.6 & 97.8 & 100.7 & 90.1 & 91.6 & 89.4 & 83.2 & 80.7 & 91.3 & 86.1 \\
\hline United Kingdom & 100 & 100.1 & 95 & 86.9 & 88.8 & 92.4 & 94 & 87 & 82.2 & 88.1 \\
\hline Norway & 103.6 & 101.3 & 106.8 & 98.4 & 103.6 & 100.5 & 101.6 & 105.1 & 104.9 & 109.4 \\
\hline Switzerland & 100.7 & 97.2 & 85.9 & 79.6 & 79.2 & 80.3 & 76.1 & 76.6 & 77.4 & 75.2 \\
\hline Former Yugoslav Republic of Macedonia & 110.2 & 131.1 & 118.7 & 79.7 & 81.5 & 72.6 & 64.4 & 62.3 & & \\
\hline
\end{tabular}

*Source: Database-Eurostat-European Commision

Today's social, functional logistics chain is a basic requirement for the profitability of growing industrial sectors. Therefore, successful transport is considered to be based on the current market demand, which requires cooperation through the administrative sector. According to Eurostat data, the collection presented on the graph below, is based on the Regulation (EC) 91/2003 of the European Parliament and of the Council of 16 December 2002 on Rail transport statistics. Data displayed in Figure 3 cover the rail transport of goods which relate rail goods transport in the Member States on its national territory. 


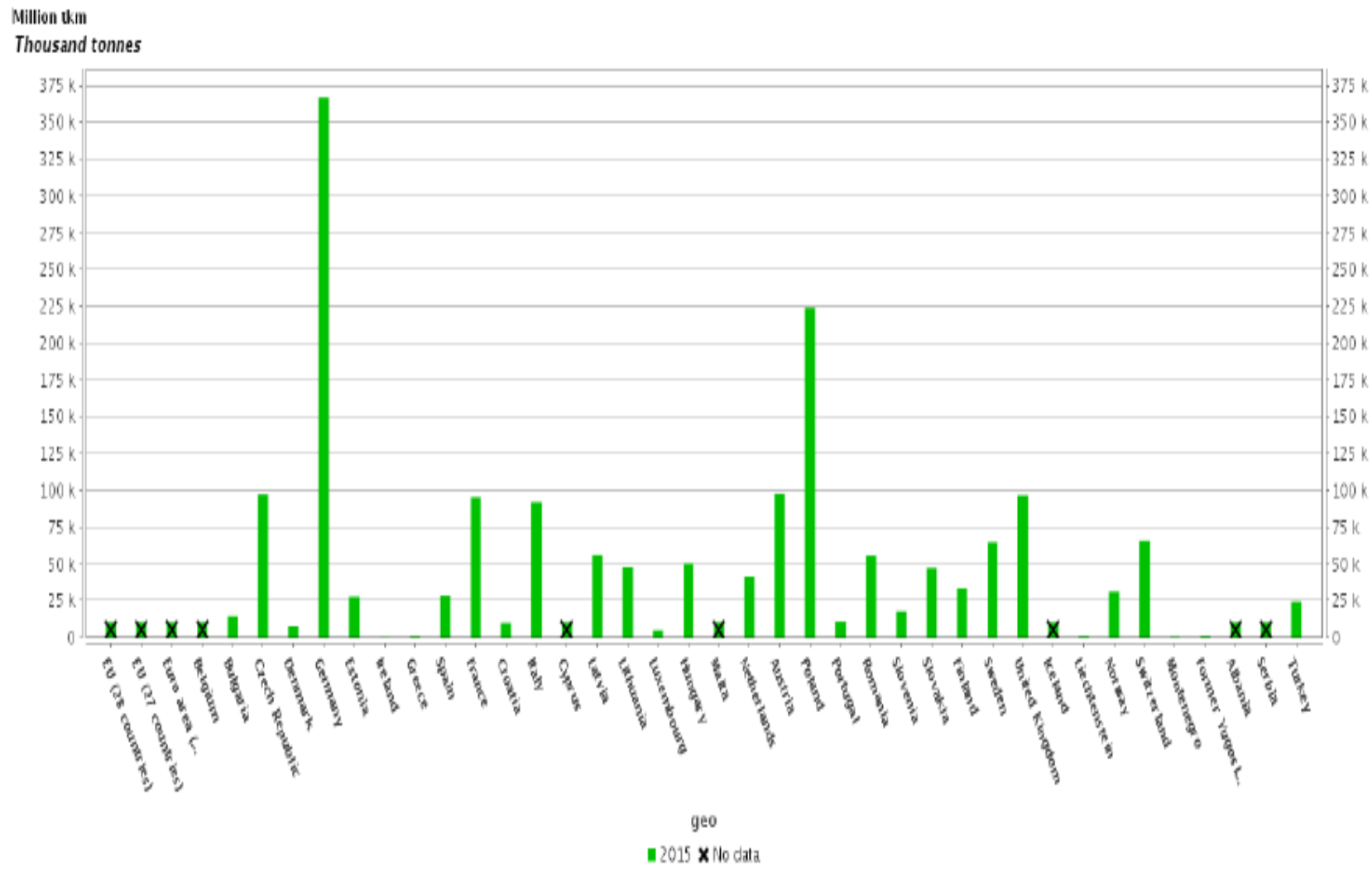

Figure 3 Goods transport by rail in the Europe [10]

Member States may exclude railway undertakings which operate entirely or mainly within industrial and similar installations, including harbours. They are not covered in above mentioned statistics.

Monitoring of freight rail transportation can be accessed from the point of view:

- Safety, which has a first share in all activities related to the transport of dangerous goods.

- Emphasis is placed on prevention, training, education and carefully focused information it is important that the freight transportation is feasible in the business sector.

- In order to ensure transport as profitable and logistically efficient, emphasis is put on the quality and conditions of infrastructure, also on transport safety and on careful management and supervision.

\section{Conclusions}

In view of a much broader societal perspective there is the relative good environmental performance of freight rail transportation as mitigation of climate change is concerned, although freight rail transportation has lost it favourable performance regarding air quality at the cost of road transport. Today's global trend is, where legislation has forced the truck industry to significantly reduce emissions.
A large proportion of the freight transportation takes places by rail. This is much safer than by truck, because these types of transport often have to travel through urban areas in order to reach their destination.

According the problematic presented in this paper we can say the most important advantages of freight railway infrastructure:

- independence of roads traffic density,

- possibility of transporting dangerous goods,

- large capacity of the wagon load,

- minimum weather dependency,

- minimum wagon's and locomotive's failure

When we want to choose the most suitable mode of transportation we take into account:

- cost of transport

- ability to create networks

- railway safety

- environment protection

\section{Acknowledgements}

This paper is part of a project that has received funding from the European Union's Horizon 2020 research and innovation programme under grant agreement No. 723274. 


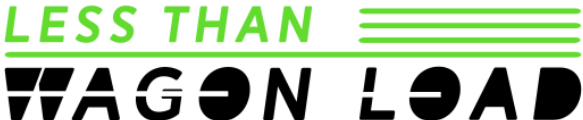

http://www.lessthanwagonload.eu

\section{References}

[1] Intergovernmental Organisation for International Carriage by Rail. [Online], Available: http://otif.org/e n/?page_id=17[17 July 2018], 2018.

[2] Development of international rail freight corridors.[Online], Available: http://mirinitiative.com/projects/white-book/joaquin-otero/thedevelopment-of-international-rail-freight-corridors-achallenge-for-spanish-railways.html. [1 July 2018], 2018.

[3] Infrabel. [Online], Available: www.infrabel.be, [26 July 2018], 2018.

[4] European Railway Agency: [Online], Available: http://www.era.europa.eu/DocumentRegister/Documents/TO\%20DE\%20error\%20in\%20 WAG\%20TSI.pdf. [20 July 2018], 2018.

[5] Rail freight transport in the EU: still not on the right track, Special Report, [Online], Available: https://www.eca.europa.eu/Lists/ECADocuments/SR1 6_08/SR_RAIL_FREIGHT_EN.pdf, 2016.

[6] Commission regulation (EU) No 321/2013 of 13 March 2013 concerning the technical specification for interoperability relating to the subsystem 'rolling stock
- freight wagons' of the rail system in the European Union and repealing Decision 2006/861/eccommission regulation (EU), 2013.

[7] Rail freight oriented network [Online], Available: https://ec.europa.eu/transport/modes/rail/infrastructure s/rail_freight_oriented_network_en, [7 Aug 2018], 2018.

[8] Efficiency railway operations and infrastructure management. [Online], Available: https://www.itfoecd.org/efficiency-railway-operations-andinfrastructure-management-roundtable, [27 July 2018], 2018.

[9] Recognition of hazardous goods. [Online], Available: http://europa.eu/rapid/press-release_IP-091167_en.htm. [17 June 2018], 2018.

[10] Database-Eurostat-European Commission. [Online], Available: https://ec.europa.eu/eurostat/data/databas e. [27 Aug 2018], 2018.

\section{Review process}

Single-blind peer review process. 